\title{
PEMBERDAYAAN MASYARAKAT MELALUI BIDANG USAHA HOME INDUSTRY DALAM MENINGKATKAN KESEJAHTERAAN MASYARAKAT
}

\author{
${ }^{1}$ Suminartini, ${ }^{2}$ Susilawati \\ 1, 2 Program Studi Pendidikan Masyarakat IKIP Siliwangi, Cimahi, Jawa Barat, Indonesia \\ ${ }^{1}$ suminartini27@gmail.com
}

Received: Juli, 2020; Accepted: September, 2020

\begin{abstract}
Community empowerment is an effort made to increase the potential and abilities possessed by individuals or communities so that they can improve their standard of living in society. Home industry is a home business that is engaged in certain industrial fields that have a limited workforce, which can absorb unemployment and empower the people around them. This study aims to (1) describe the existence of the home industry in the Kp.Kihapit Timur area RT 03 RW 20, (2) Know the home industry planning in the Kp.Kihapit Timur area RT 03 RW 20, (3) Know the process of existence home industry in the Kp. Kihapit Timur RT03 RW 20, (4) Knowing the obstacles experienced by home industry business owners in developing their business. This research is a qualitative research with descriptive exposure. The techniques and methods used in this research are through observation, interviews, and documentation. Based on the results of this study, the veil home industry in the Kp. Kihapit Timur RT 03 RW 20 Leuwigajah Subdistrict, South Cimahi District, can empower the surrounding community, especially housewives, can help people with low economies in improving their standard of living and can also reduce unemployment.
\end{abstract}

Keywords: Community Empowerment, Home Industry, Entrepreneurship

\begin{abstract}
Abstrak
Pemberdayaan masyarakat merupakan suatu usaha yang dilakukan untuk meningkatkan potensi dan kemampuan yang dimiliki oleh individu atau masyarakat sehingga mereka dapat meningkatkan taraf hidupnya di masyarakat. Home industry merupakan suatu usaha rumahan yang bergerak dalam bidang industry tertentu yang memiliki tenaga kerja yang terbatas, yang dapat menyerap pengangguran dan memberdayakan masyarakat yang ada disekitarnya. Penelitian ini bertujuan untuk (1) Mendeskripsikan keberadaan home industry yang ada di wilayah Kp.Kihapit Timur RT 03 RW 20, (2) Mengetahui perencanaan home industri yang ada di wilayah Kp.Kihapit Timur RT 03 RW 20, (3) Mengetahui proses adanya home industry yang ada di wilayah Kp. Kihapit Timur RT03 RW 20, (4) Mengetahui hambatan-hambatan yangdi alami oleh pemilik usaha home industry dalam mengembangkan usahanya. Penelitian ini adalah penelitian kualitatif dengan pemaparan secara deskripsi. Teknik dan metode yang digunakan dalam penelitian ini yaitu melalui observasi, wawancara, dan dokumentasi. Berdasarkan hasil dari penelitian tersebut bahwa home industry kerudung yang berada di wiayah Kp. Kihapit Timur RT 03 RW 20 Kelurahan Leuwigajah Kecamatan Cimahi Selatan, dapat memberdayakan masyarakat sekitarnya terutama ibu-ibu rumah tangga, dapat membantu masyarakat yang berekonomi rendah dalam meningkatkan taraf hidupnya dan juga dapat mengurangi penganguran.
\end{abstract}

Kata Kunci : Pemberdayaan Masyarakat, Home Industri, Kewirausahaan

How to Cite: Suminartini \& Susilawati. (2020). Pemberdayaan Masyarakat Melalui Bidang Usaha Home Industry Dalam Meningkatkan Kesejahteraan Masyarakat. Comm-Edu (Community Education Journal) 3 (3), 226-237. 


\section{PENDAHULUAN}

Dengan adanya perkembangan zaman dan era globalisasi berdampak pada meningkatnya kebutuhan masyarakat terhadap sandang, pangan, dan papan yang diiringi pula dengan meningkatnya jumlah penduduk. Menurut badan pusat statistic (BPS) per maret 2017, angka kemiskinan Jawa Barat mengalami penurunan yang tidak signifikan yaitu dari $8,77 \%$ menjadi $8,71 \%$ atau hanya mengalami penurunan $0,006 \%$ dari target $1 \%$ per tahun, yang artinya masih ada 4juta warga Jawa Barat yang hidup dalam garis kemiskinan. Adapun program yang dikeluarkan untuk penangggulangan kemiskinan yang telah diterima keluarga miskin yaitu 4 (empat) program bantuan diantaranya Kartu Indonesia Pintar (KIP), Kartu Indonesia Sehat (KIS), Program Keluarga Harapan (PKH), dan Beras Sejahtera (RASTA) sebagaimana dilaporkan oleh Kompas.com (Maret, 2017).

Kenyataan di lapangan, khususnya di wilayah Jawa Barat, banyak masyarakat yang masih menganggur. Hal tersebut dapat dikatakan bahwa kesejahteraan umum di Jawa Barat dapat digambarkan berdasarkan tingkat kemiskinan penduduknya, yaitu semakin rendah tingkat kemiskinan menggambarkan semakin tinggi kesejahteraan penduduk di Indonesia.

Meskipun beberapa daerah di Jawa Barat termasuk kedalam daerah yang berpendapatan lebih melalui industri kreatif seperti kabupaten garut yang terkenal dengan sepatu kulit, tas kulit, jaket kulit tetapi tidak menjamin kesejahteraan penduduknya. Menurut Simatupang (2007), Industri kreatif yaitu industri yang mengandal keterampilan, talenta dan kreatifitas yang berpotensi dalam meningkatkan kesejahteraan. Sedangkan menurut John Howkins (dalam Chabib Soleh, 2014 : 200) industri kreatif /ekonomi kreatif adalah kegiatan ekonomi dimana input dan outputnya adalah gagasan, karena hanya dengan modal gagasan seseorang yang kreatif dapat memperoleh penghasilan yang sangat layak.

Berdasarkan uraian diatas dalam menanggulangi kemiskinan masyarakat harus lebih kreatif, inovatif dan terampil agar dapat memenuhi segala kebutuhannya dengan menciptakan lapangan usaha baru (berwirausaha). Berwirausaha merupakan salah satu usaha untuk mengentas kemiskinan dan mengurangi tingkat penganguran. Adapun salah satu contoh wirausaha tersebut yaitu industri kreatif, home industry dan sebagainya. Home industry merupakan salah satu usaha yang dilakukan dirumah, usaha home industry dapat menyerap pengangguran dan memberdayakan masyarakat yang ada disekitarnya.

Aktivitas pemberdayaan masyarakat berada di tangan masyarakat itu sendiri dengan bertitik tolak dari masyarakat, dilaksanakan oleh masyarakat dan manfaatnya untuk masyarakat atau dengan istilahlain pendidikan berbasis pada masyarakat. Hal ini merupakan salah satu cara untuk membangun rasa memiliki dan tanggung jawab dalam membangun dan mengembangkan program pemberdayaan di dalam masyarakat. Hal ini, diperkuat dengan pendapat Yunus (2004: 3) yang mengungkapkan bahwa terdapat lima prinsip dasar yang patut diperhatikan dalam proses pemberdayaan masyarakat, diantaranya adalah : (1) keperdulian terhadap masalah, kebutuhan dan potensi/ sumberdaya masyarakat; (2) kepercayaan timbal balik dari pelayan program dan dari masyarakat pemilik program; (3) fasilitasi (pemerintah) dalam membantu kemudahan masyarakat dalam berbagai proses kegiatan; (4) adanya partisipatif, yaitu upaya melibatkan semua komponen lembaga atau individu terutama warga masyarakat dalam proses kegiatan dan (5) mengayomi peranan masyarakat dan hasil yang dicapai.

Salah satu contoh aktifvitas pemeberdayaan masyarakat yaitu home industry (industri rumahan). Home industry ada berbagai macam jenisnya yaitu dalam pembuatan makanan 
seperti kue,roti dan sebagainya. Adapula home industry dalam pembuatan kaus kaki dan pembuatan kerudung. Salah satu contoh Home industri yang bergerak dalam pembuatan kerudung terdapat di daerah Leuwigajah bertepatan di Kp. Kihapit Timur RT 03 RW 20 Kelurahan Leuwigajah Kecamatan Cimahi Selatan Kota Cimahi. Usaha ini sangat membantu masyarakat sekitar dalam segi ekonomi karena sulitnya mencari pekerjaan dengan keterbatasan pendidikan dan usia membuat banyak warga masyarakat sekitar bekerja di Home Industry tersebut.

Adapula diantara mereka yang bermitra dengan pemilik usaha tersebut, sehingga industri rumahan ini banyak menjamur di daerah ini. Industri rumahan ini sudah berdiri kurang lebih sejak tahun 2007. Peran fashion sangat berpengaruh terhadap industri ini karena dengan adanya fashion, industri ini tetap ada. Selain itu, seiring dengan perkembangan zaman, berbagai model kerudungpun tersedia di industri rumahan ini. Seperti kerudung segi empat, kerudung pashmina, dan macam-macam model lainnya dengan berbagai jenis dan bahan.

Home industry ini sebagian besar pegawainya adalah ibu-ibu rumah tangga yang berada disekitar home industry tersebut, dengan adanya usaha tersebut menjadi sumber penghasilan ataupun tambahan bagi masyarakat sekitarnya dan menjadi lapangan kerja baru bagi masyarakat ataupun anak-anak remaja yang tidak mengenyam sekolah menengah atas tetapi memiliki keahlian.

Pertumbuhan home industry merupakan industri yang mempunyai peranan penting dalam menunjang pertumbuhan ekonomi daerah. Perkembangan sektor industry dalam pembangunan di Indonesia tidak lepas dari peranan dan keberadaan industry kecil, kerajinan rakyat, disamping berkembangnya home industry akan tetapi industri ini selalu menghadapi berbagai masalah atau kesulitan dalam mengembangkan usahanya.

Permasalahan yang ditemui salah satunya yaitu modal. Dalam hal ini, pemilik home industry tersebut masih memerlukan modal yang cukup agar usaha tersebut bisa berjalan secara terus menerus dan berkesinambungan. Selain itu, pengelolaan juga menjadi salah satu masalah yang dihadapi. Pengelolaan disini lebih kepada pengadministrasian yang kurang tertib dan masih dikelola secara langsung oleh pemiliknya. Pengelolaan terhadap pegawai serta pengelolaan keuangan merupakan faktor penting yang harus dimiliki oleh setiap industri agar usaha tersebut dapat berjalan lancar. Pemasaran juga menjadi kendala yang dihadapi oleh pemilik home industry tersebut. Kurangnya jaringan dan kemitraan yang dimiliki oleh pemilik usaha tersebut menjadi salah satu hal yang sangat berpengaruh terhadap kelancaran kegiatan usaha yang dimiliknya.

Pemilik usaha home industry seharusnya memiliki kemampuan untuk mengelola agar usaha tersebut dapat berjalan secara baik sehingga dapat membantu kesejahteraan masyarakat sekitar yang sebagian besar bekerja pada usahanya tersebut. Pemberdayaan yang dilakukan oleh home industry tersebut sangatlah berpengaruh dalam meningkatkan keterampilan masyarakat sehingga dengan keterampilannya tersebut, masyarakat dapat memenuhi kebutuhan hidupnya. Maka atas pemikiran tersebut, penulis tertarik mengemukakan topik penelitian dengan judul "Pemberdayaan Masyarakat Melalui Bidang Usaha Home Industry Dalam Meningkatkan Kesejahteraan Masyarakat". 


\section{LANDASAN TEORI \\ Pengertian Kesejahteraan Masyarakat}

Kesejahteraan masyarakat adalah suatu kondisi masyarakat dimana telah terpenuhinya kebutuhan dasar berupa, terpenuhinya sandang, pangan, papan, kesehatan pendidikan, lapangan pekerjaan. Menurut Horton dan Hunt (1987 :59) masyarakat adalah sekumpulan manusia yang secara relative mandiri, yang hidup secara bersama-sama cukup lama, yang mendiami suatu wilayah madiri, memiliki kebudayaan yang sama, dan melakukan sebagian besar kegiatannya dalam kelompok tersebut.

Menurut Friedlander dalam Suud (2006:8) pengertian kesejahteraan masyarakat (sosial) yaitu suatu sistem yang terorganisasi dari pelayanan-pelayanan dan lembagalembaga sosial , yang di maksudkan untuk membantu individu-individu atau kelompok agar mencapai tingkat hidup dan kesehatan yang memuaskan dan hubungan-hubungan personal dan sosial yang memberi kesempatan kepada mereka untuk mengembangkan seluruh kemampuannya untuk meningkatkan kesejahteraannya sesuai dengan kebutuhan-kebutuhan keluarga dan masyarakat.

\section{Konsep Dasar Kewirausahaan}

Menurut Prof. H.D. Sudjana (2010:117) Kewiraushaan adalah sikap dan periaku. Sedangkan wirausaha adalah orang yang inovatif, antisipatif, inisiatif, pengambil resiko, dan berorientasi laba (John Kao,1991 :14). Meredith (1989) menabahkan bahwa wirausaha adalah orang yang mampu mengantisipasi peluang usaha, mengelola sumber daya manusia guna mendapatkan keuntungan, dan bertindak tepat menuju sukses.

Menurut Kasmir (2006:16) wirausahawan (entrepreneur) adalah orang yang berani mengambil resiko untuk membuka usaha dalam berbagai kesempatan. Berani mengambil resiko yang berarti bermental mandiri, dan berani memulai usaha tanpa rasa takut atau cemas sekalipun dalam kondisi tidak pasti.

Sedangkan menurut Schumpeter dalam Alma (2011 : 24), wirausaha adalah orang yang mendobrak sistem ekonomi yang ada dengan memperkenalkan barang dan jasa yang baru, dengan menciptakan bentuk organisasi baru atau mengolah bahan baku baru. Sukses dalam berwirausaha tidak diperoleh secara tiba-tiba atau instan melainkan diperoleh dengan penuh perencanaan, memiliki visi, misi, kerja keras, dan memiliki keberanian serta bertanggung jawab.

Sedangkan menurut Sumah amidjaja (1980) dalam buku Prof. H. D. Sudjana Pendidikan Nonformal (2010 :117), menjelaskan bahwa kegiatan wirausaha mencangkup bidang, industry kecil, pelayanan dan perdagangan.

Maka dapat disimpulkan dari beberapa pendapat diatas bahwa berwirausaha adalah seseorang yang mempunyai sikap yang inovatif, dapat membaca peluang usaha dan berani mengambil resiko untuk membuka usaha meskipun dalam keadaan yang tidak pasti.

\section{Konsep Home Industry / Industri Rumahaan}

Home dapat diartikan sebagai rumah, tempat tinggal sedangkan industry adalah kerajinan atau produk barang yang dihasilkan. Home industry merupakan 
perusahaan kecil yang kegiatan ekonominya dipusatkan dirumah. Menurut UU No.3 Tahun 2014 Tentang Perindustriaan, industri adalah suatu usaha atau kegiatan pengelolaan bahan mentah atau barang setengah jadi menjadi barang jadi yang memiliki nilai tambah untuk mendapat keuntungan.

Home industry juga dapat diartikan sebagai industri rumah tangga atau industri rumahan karena termasuk usaha kecil yang dikelola oleh keluarga. Home industry/ Industri rumahan adalah tempat tinggal yang merangkap sebagai tempat usaha baik itu berupa usaha jasa, kantor hingga perdagangan. Usaha home industry dapat menyerap pengangguran dan memberdayakan masyarakat yang ada disekitarnya.

Home industry / industri rumahan menurut Muliawan, $2008: 3$ merupakan suatu unit usaha atau perusahaan dalam skala kecil yang bergerak dalam bidang industri tertentu. Menurut UU No.3 Tahun 2014 industri rumahan adalah industry yang mempunyai tenaga kerja yang terbatas.

Keberdaan industri rumahan / home industry sangat berpengaruh terhadap perubahan sosial, ekonomi masyarakat. Selain menjadi tambahan pendapatan bagi masyarakat karena dapat dijadikan menjadi mata pencaharian baru untuk memenuhi kebutuhan sehari-hari.

\section{METODE}

\section{Lokasi Dan Waktu Penelitian}

Lokasi penelitian adalah tempat dimana penelitian akan dilakukan beserta jalan dan kotanya. Dalam penelitian ini peneliti mengambil lokasi di wilayah Cimahi,khususnya di home industry milik Bapak Diar yang bertepatan di Kp. Kihapit Timur RT 03 RW 20 Kelurahan Leuwigajah Kecamatan Cimahi Selatan Kota Cimahi, home industry ini merupakan salah satu usaha yang bergerak dalam pembuatan kerudung yang sedang menjamur di daerah ini. Keberadaan usaha ini sangat membantu masyarakat sekitar terutama ibu-ibu rumah tangga yang tidak bekerja, home industry ini membuat kerudung mulai dari model segi empat, pashmina, dan dari berbagai jenis bahan.

Waktu penelitian di lakukan pada siang hari dikarenakan karyawan atau pekerja yang sebagian besar adalah ibu-ibu rumah tangga masih disibukan dengan kegiatan dirumahnya masingmasing. Para pekerja ini (ibu-ibu ) mempunyai tugas dan peran masing-masing dalam proses pembuatan kerudung seperti dalam memotong bahan (setting) sesuai dengan ukuran yang telah ditentukan, merawis (memberikan model pada kerudung ), menjahit (memasang label merk pada kerudung) dan packing (melipat kerudung pada plastik ). Kegiatan ini biasanya dilakukan dirumah pemilik usaha maupun dirumah pegawai yang dipercaya oleh pemilik usaha.

Berbeda dengan yang dilakukan oleh Bapak Diar, disini dia selaku pemilik sekaligus sebagai quality control ( QC ) terhadap proses produksi yang ada dilapangan, sehingga semua proses yang telah terjadi dikepul dirumahnya hal ini dilakukan untuk mengetahui kemungkinan adanya kesalahan yang dilakukan oleh tiap-tiap bagian produksi. Sehingga hanya pada proses packing saja kegiatan produksi dilakukan dirumahnya.

\section{Subjek yang Diteliti}

Subjek penelitian adalah keseluruhan dari sumber informasi yang dapat memberikan data yang sesuai dengan masalah yang diteliti. (menurut Suharsimi Arikunto1989 : 143). Subjek 
penelitian merupakan sumber informasi untuk mencari data dan mengungkap masalah-masalah penelitian, atau lebih dikenal sebagai informan yaitu orang yang dapat memberikan informasi mengenai situasi dan kondisi latar penelitian.

Subjek penelitian yaitu seorang pengelola home industry beserta tiga orang karyawan di home industry tersebut, sebab keberadaan usaha ini berdampak pada warga masyarakat sekitar karena telah diberdayaka baik dari segi keterampilan maupun dari segi ekonomi.

\section{Prosedur Penelitian}

Menurut Hamid Darmadi (20014 : 287) pendekatan kualitatif adalah proses penelitian dan pemahaman yang berdasarkan pada metodologi yang menyalidiki suatu fenomena sosial dan masalah manusia. Pada pendekatan ini peneliti membuat suatu gambaran komleks, meneliti ktkata, laporan terperinci dari responden dan melakukan studi pada situasi yang dialami. Penelitian ini menggunakan pendekatan kualitatif yang menghasilkan data deskriptif berupa kata-kata tertulis.

\section{Metode Pengumpulan Data}

Metode yang digunakan dalam penelitian ini menggunakan pendekatan kualitatif yaitu penelitian yang menghasikan data deskriptif berupa kata-kata tertulis maupun lisan dari orangorang dan perilaku yang diamati. Menurut Moleong (2002:112 )sumber data kualitatif adalah kata-kata dan tindakan selebihnya merupakan data tambahan seperti dokumen dan lainnya.Sedangkan dalam mengumpulkan data dalam penelitian ini yaitu melalui wawancara, observasi, dan dokumentasi.

\section{HASIL DAN PEMBAHASAN}

Dari hasil observasi dan wawancara yang dilakukan kepada pegawai home industry dan pemilik sekaligus pengelola usaha tersebut diperoleh data bahwa:

\section{Keberadaan Home Industri Kerudung di RT 03 RW 20 Kelurahan Leuwigajah}

Berdasarkan hasil wawancara dengan pegawai home industry diperoleh informasi mengenai keberadaan usaha home industri yang berada di Kp. Kihapit Timur RT 03 RW 20 Kel. Leuwigajah Kec. Cimahi Selatan. Keberadaan usaha ini sangat membantu masyarakat sekitarnya karena selain menjadi mata pencaharian tetapi dapat menjadi sumber pengahasilan tambahan maupun utama untuk memenuhi kebutuhan sehariharinya sehingga masyarakat terutama ibu-ibu menekuni (bekerja) di home industry ini. Keberadaan usaha home industry sangat dirasakan oleh masyarakat terutama masyarakat yang berada disekitar home industry tersebut dan masyarakat dengan keadaan ekonomi rendah. Adanya usaha ini memberikan dampak yang baik bagi masyarakat terutama untuk ibu-ibu rumah tangga yang membuat mereka memiliki keterampilan dan juga untuk masyarakat yang masih menganggur karena tingkat pendidikan yang masih rendah dan jumlah lapangan kerja yang terbatas membuat usaha ini menjadi salah satu usaha yang dijadikan sebagi mata pencaharian utama, karena usaha ini dapat memenuhi kebutuhan sehari-harinya.

Berdasarkan tentang tujuan kesejahteraan menurut Fahrudin (2005: 10) adalah tercapainya kehidupan yang sejahtera yaitu terpenuhinya kebutuhan pokok seperti sandang, pangan, kesehatan,perumahan dan relasi-relasi sosial yang harmonis dengan lingkungan. 
Home industry atau usaha rumahaan yang berproduksi dalam pembuatan kerudung ternyata selain dapat menambah keterampilan, menambah pendapatan tetapi juga hasil limbah yang dihasilkan dari kegiatan produksipun dapat menambah penghasilan juga seperti hasi potong kain, limbah yang dihasilkan dapat digunakan sebagai tali atau dijual kepada glosir-glosir, toko-toko elektronik yang digunakan sebagai tali. Sedangkan bentuk plastik kones dapat dijual kepada penjual barang bekas dan limbah dalam bentuk benang dapat dimanfaatkan untuk pembuatan bantal. Hasil limbah dari proses pembuatan kerudung tidak ada yang terbuang tetapi dapat bermanfaat dan dapat dimanfaatkan asalkan masyarakat dapat jeli dalam melihat peluang yang ada.

Adapun manfaat dari adanya usaha home industry, diantaranya adalah:

Menjadi sumber penghasilan, baik penghasilan utama maupun penghasilan tambahan

Keberadaan usaha home industry dapat dijadikan sumber penghasilan utama bagi masyarakat yang hidup dengan ekonomi rendah sehingga dengan adanya usaha ini dapat membantu mereka untuk memenuhi segala kebutuhannya, sedangkan bagi sebagian masyarakat yang hidup berkecukupan usaha ini dijadikan untuk menambah penghasilannya dan untuk mengisi waktu luang tapi menghasilkan uang.

\section{Membantu dalam terpenuhinya kebutuhan hidup}

Usaha home industry sangat membantu para pegawainya terutama pegawai yang berekonomi rendah sehingga dengan adanya usaha ini dapat membantu mereka dalam memenuhi kebutuhan hidupnya selain itu usaha ini juga dapat menjadi sumber pendapatan utama bagi mereka.

Berdasarkan pengertian pemberdayaan menurut Suzanne Kindevatter dalam bukunya Nonformal education as an empowering (1979) dalam Djuju Sudjana (2000:77) adalah pendidikan khususnya pendidikan luar sekolah (PLS) sebagai proses pemberdayaan adalah suatu pendekatan pendidikan yang bertujuan untuk meningkatkan pengertian dan pengendalian diri terhadap kehidupan sosial, ekonomi, dan politik sehingga mereka mampu untuk meningkatkan taraf hidupnya dalam masyarakat.

\section{Menjadi mata pencarian baru terutama untuk ibu-ibu rumah tangga.}

Usaha home industry kerudung yang ada di daerah Leuwigajah khususnya di Kp. Kihapit Timur RT 03 RW20 terasa sangat membantu terutama untuk ibu-ibu rumah tangga karena dapat dijadikan mata pencarian baru untuk menambah penghasilan dalam memenuhi kebutuhan mereka.

\section{Menambah keterampilan}

Keberadaan usaha home industry yang berada di Kp.Kihapit Timur RT03 RW 20 merupakan usaha rumahan yang awalnya usaha ini didirikan hanya untuk menambah penghasilan pemilik usaha tersebut tetapi dapat memberdayakan masyarakat sekitarnya sehingga memiliki keterampilan dalam pembuatan kerudung terutama untuk ibu-ibu rumah tangga. Dengan adanya usaha ini mereka dapat memperoleh keterampilan baru dan juga penghasilan tambahan. 


\section{Mengurangi pengangguran}

Home industry pembuatan kerudung tidak hanya bermanfaat untuk memenuhi kebutuhan tetapi juga dapat mengurangi pengangguran yang ada akibat dari terbatasnya lapangan pekerjaan dengan tingkat pendidikan masyarakat yang rendah sehingga mereka bekerja diusaha home industry tersebut dan juga dengan tidak adanya persyaratan dalam perekrutan pegawai baik dari latar belakang pendididkan maupun dari pengalaman kerja membuat masyarakat yang menganggur baik pemuda maupun pemudinya bekerja di home industry ini.

Home industry merupakan salah satu usaha yang dapat memberdayakan masyarakat seperti menurut Ife (1995 : 182) dalam buku "community development creating community alternatives vision analysis and practice" yaitu upaya penyediaan kepada orang-orang atas sumber kesempatan, pengetahuan dan keterampilan untuk meningkatkan kemampuan mereka menentukan masa depannya dan untuk berpartisipasi didalam mempengaruhi kehidupan komunitas mereka.

Usaha home industry selain dapat memberdayakan masyarakat sekitar baik dalam segi keterampilan, kreatifitas, kemampuan dalam berwirausaha maupun dalam segi pola fikir (cara berfikir ) masyarakat agar lebih maju tetapi juga dapat membantu mereka dalam memenuhi kebutuhan hidupnya baik itu kebutuhan pokok sehari-hari maupun kebutuhan tak terduga. Keberadaan usaha ini sangat dirasakan oleh masyarakat, terutama oleh masyarakat yang masih hidup dibawah garis kemiskinan, masyarakat yang tidak memiliki pekerjaan tetap maupun pengangguran karena latar pendidikan yang tidak memenuhi standar untuk bekerja diperusahan-perusahan besar.

Usaha home industri tidak memberikan persyaratan kepada pegawai yang akan bekerja diusaha ini sehinga masyarakat yang menganggur terutama yang pendidikannya masih rendah lebih memilih bekerja di usaha ini walaupun upah yang diberikan tidak sama seperti upah pada perusahan-perusahan besar mereka tetap mau bekerja disini selain lokasi yang dapat dijangkau dari rumah, tidak ada aturan yang mengikat, jam kerja dilakukan dari pagi sampai sore saja. Apabila pegawai yang sudah ahli gaji yang diperoleh perbulan diusaha home industry ini dapat bersaing dengan upah yang bekerja diperusahaan besar karena home industry ini menggunakan sistem borongan yang tergantung pada kecepatan pegawai dalam bekerja.

Membuka usaha home industry kerudung ternyata tidak semua orang maupun pegawai yang bekerja diusaha tersebut berkeinginan memiliki usaha sendiri karena terkendala dari modal yang harus dimiliki yang mungkin teralu besar bagi mereka, selain itu tanggung jawab yang harus dipikul cukup berat, kemudian cara merekrut karyawan yang dapat diandalkanpun menjadikan salah satu alasan, dan peran mitra kerja yang mendukung dalam berkembangnya usaha tersebut turut berpengaruh.

Dengan adanya beberapa kendala tersebut membuat pegawai memilih menjadi pegawai saja karena beberapa factor tersebut dirasakan cukup berat untuk memiliki usaha sendiri, karena apabila memiliki keinginan saja tapi tidak memiliki modal dan mitra usaha, usaha tersebut tidak akan berkembang ditambah dengan minimnya pengetahuan mengenai pengelolaan dapat menjadi kendala juga dan latar belakang pendidikan 
maupun pengalaman dapat berpengaruh dalam menjalankan suatu usaha apabila menjadi seorang pemilik / pengelola.

Adanya usaha home industry yang berada di Kp. Kihapit Timur RT 03 RW 20 yang sangat dirasakan oleh masyarakat diharapkan agar tetap maju dan berkembang dalam menjalankan usahanya, hal ini diharapakan oleh para pegawai agar para pekerja yang menggantungkan hidupnya pada usaha ini dapat terus bekerja sehingga mereka dapat memenuhi berbagai kebutuhan hidupnya,karena manfaat dari usaha ini sangat berdampak bagi masyarakat sekitar khususnya. Menurut para pegawai usaha home industry kedepannya dapat menjadi tempat usaha yang besar seperti menjadi usaha konveksi yang memiliki order yang tak pernah terhenti sehingga pegawai tidak ada kata libur untuk menunggu order selanjutnya.

\section{Pengelolaan dalam usaha home industri kerudung yang ada di RT 03 RW 20 Kelurahan Leuwigajah}

Kegiatan usaha home industry yang didirikan oleh Bapak Diar dan keluarga pada tahun 2016 yang bertepatan di Kp. Kihapit Timur RT 03 RW 20 Kel. Leuwigajah Kec. Cimahi Selatan Kota Cimahi, sangat membantu masyarakat sekitar terutama ibu- ibu rumah tangga, dan masyarakat yang masih hidup dibawah garis kemiskinan sehingga usaha ini sangat diandalkan oleh mereka untuk menjadi sumber mata pencaharianya sehingga dapat memenuhi kebutuhan hidupnya.

Dalam menjalankan usahanya seorang pemilik/ pengelola (wirausaha) harus mampu mengantisipasi peluang usaha dan menciptakan atau mengeola bahan baku baru untuk mendapatkan keuntungan seperti usaha home industry ( Bapak Diar).

Berdasarkan teori menurut Prof. H. D Sudjana (2010:117) mengenai pengertian kewirausahaan yang ditambahkan oleh Meredith (1989) bahwa wirausaha adalah orang yang mampu mengantisipasi peluang usaha, mengelola sumber daya manusia guna mendapatkan keuntungan, dan bertindak tepat menuju sukses.

Dalam mengelola usahanya ini seorang pemilik harus memiliki proses perencanaan yang matang contohnya modal, modal sangat dibutuhkan dalam mendirikan suatu usaha dan menjadi hal yang utama, khususnya modal digunakan untuk pengupahan pegawai, pembelian peralatan produksi baik peralatan utama maupun penunjang, modal juga digunakan untuk menyediakan fasilitas yang memadai. Modal sangat berpengaruh terhadap berkembangnya suatu usaha, baik itu modal yang berasal dari pribadi maupun dari bermitra.

Perekrutan pegawai di usaha home industry tidak seperti perekrutan diperusahanperusahan yang memiliki kriteria dan persyaratan cukup banyak. Di home industry perekrutan pegawai dilakukan dengan bertanya kepada pegawai lainnya apabila memiliki teman atau saudara yang tidak bekerja (menganggur) atau dapat datang sendiri ke tempat pemilik usaha tersebut. Dalam perekrutan pegawai tidak ada proses seleksi maupun persyaratan yang harus dibawa tetapi, pemilik memilih pegawai hanya dengan melihat karakter dari calon pegawai, dilihat dari kerapihan hasil kerja, dan penguasaan terhadap alat produksi. 
Dalam mengembangkan usaha, home industry tidak lepas dari peran mitra kerja karena semua usaha home industry yang ada khususnya di Kp. Kihapit Timur merupakan home industry yang kegiatan usahanya tidak dilakukan oleh perorangan tetapi dengan sitem makloon yang hanya melakukan kegiatan produksi saja. Sedangkan untuk bahan mentah (kain) sudah ada pemasok atau pihak 1(pertama) dan proses pemasaranpun dilakukan oleh pihak 1 (pertama). Dalam proses pengupahanpun peran mitra sangat berpengaruh karena upah yang diberikan pemilik kepada pegawai merupakan sistem borongan dan tiap bagian produksi upah per1 kodi telah ditentukan oleh pihak 1, sehingga pengelola tinggal mengkalkulasi jumlah yang dihasilkan oleh pegawai dalam 1 hari.

\section{Proses kegiatan home industry kerudung}

Adapun proses kegiatan dari home industry diawali dengan penyaluran bahan mentah (kain) kepada pegawai dilapangan kemudian dilakukan proses pemotongan dan setting ukuran kain sesuai dengan ukuran yang telah ditentukan dilanjutkan dengan proses rawis, atau neci atau klin sesuai dengan order pihak 1, selanjutnya masuk ke proses penjahitan label / merk, dan kemudian kerudung yang sudah jadi siap di bungkus ke dalam plastic yang sudah ada dan masuk ke proses ngepack (proses akhir) dimana kerudung siap dikirim.

\section{Hambatan-hambatan yang dialami pemilik usaha home industry kerudung}

Dalam usaha home industry terdapat hambatan-hambatan yang dialami oleh pemilik usaha baik hambatan yang terjadi selama proses kegiatan produksi maupun hambatan yang dialami secara langsung oleh pemilik usaha dalam mengembangkan usahanya seperti, hambatan dalam perekrutan pegawai yang berkualitas karena jumlah pegawai sangat berpengaruh terhadap kegiatan produksi untuk mengejar target kiriman yang diinginkan oleh pemesan. Permasalahan modalpun berpengaruh besar terhadap berkembangnya usaha home industry karena modal merupakan peran utama yang harus dimiliki oleh seorang pemilik usaha untuk menyediakan alat-alat produksi dan fasilitas penunjang dalam kegiatan produksi. Adapun salah satu cara yang dilakukan untuk mengantisipasi permasalahan yang di alami dalam kegiatan produksi yaitu pengelola atau pemilik akan ikut serta dalam proses kegiatan produksi seperti membantu dalam penyaluran bahan mentah, penjahitan label, pembungkusan kerudung dan proses pengepackan sehingga permasalah yang ada dapat terselsaikan.

Keberhasilan suatu usaha tak terlepas dari peran seorang pemilik usaha ( wirausaha) yang memilki pengalaman atau pengetahuan dalam mengelola usahanya. Adapun factor yang harus dimiliki seorang pemilik usaha yaitu memiliki sifat pekerja keras, memiliki keberanian dalam bertindak, dan bertanggung jawab atas pekerjaannya.

Berdasarkan Clelland dalam Handayani (2013:109) mengenai factor yang menentukan keberhasilan seorang wirausaha yaitu: 1. Factor internal meliputi: motivasi, pengalaman atau pengetahuan, dan kepribadian.2. Faktor eksternal meliputi: lingkungan keluarga, dan lingkungan kerja.

Faktor-faktor tersebut sangat brpengaruh terhadap berkembangnya dan suksesnya suatu usaha karena kemampua yang dimiliki oleh seorang pemilik/ pengelola sangat berpengaruh terhadap usaha yang dijalankannya, selain factor-faktor pendukung lainnya. 


\section{KESIMPULAN}

Berdasarkan hasil pengolahan data yang diperoleh melalui penelitian, kesimpulan ini bertitik tolak dari pertanyaan penelitian,yaitu:

\section{Keberdaan Home Industri di Kp. Kihapit Timur RT 03 RW 09 Kelurahan Leuwigajah Kecamatan Cimahi Selatan}

Usaha home industry kerudung ini memiliki banyak manfaat yang tadinya hanya untuk menjadi sumber penghasilan bagi pemilik usaha tersebut, tetapi secara tidak langsung dapat membantu masyarakat di sekitar dalam meningkatkan kesejahteraan ekonominya dan memberdayakannya dengan keterampilan yang diberikan dalam pembuatan kerudung terutama untuk ibu-ibu rumah tangga

\section{Proses kegiatan usaha Home Industri}

Proses kegiatan home indusri yang berada di Kp. Kihapit timur RT 03 RW20 Keluraha. Leuwigajah, meliputi:

a) Penyaluran bahan mentah kepada pegawai dilapangan

b) Pemotongan kain dan setting

c) Rawis

d) Penjahitan label / merk.

e) Pembungkusan kerudung yang sudah jadi/ packing

f) Pack

Dalam proses pemasaran barang dilakukan oleh pihak1(pertama) karena usaha home industry kerudung yang ada Kp. Kihapit Timur merupakan usaha dalam sistem makloon atau dapat dikatakan usaha ini hanya melakukan kegiatan produksi saja sementara bahan (kain) dan pemasaran dilakukan oleh pihak1(pertama).

3. Pengelolaan dalam home industry kerudung di Kp. Kihapit Timur RT 03 RW 20 Kelurahan Leuwigajah

Usaha home industry kerudung dalam menjalankan usahanya harus memiliki pengelolaan yang matang baik perencanaan pada saat berdirinya usaha tersebut maupun perencanaan yang dilakukan sambil berjalannya kegiatan usaha tersebut. Peran modal dan mitra kerjapun merupakan salah satu cara untuk mengembangkan usaha home industry kerudung, adapun modal yang digunakan dapat berasal dari modal pribadi maupun modal dari bermitra, modal digunakan untuk membeli alat produksi baik peralatan penunjang maupun peralatan utama, untuk pengupahan dan untuk menyediakan fasilitas yang memadai sehingga dapat menunjang kegiatan produksi agar berjalan lancar.

Cara merekrut pegawai di home industry kerudung tidak memakai persyaratan seperti latar belakang pendidikan, pengalaman kerja, dsb tetapi bagi orang yang tidak memiliki pekerjaan dapat datang dan bekerja diusaha ini.

\section{Hambatan yang dialami dalam mengembangkan usaha Home Industri kerudung}

Dalam membuka suatu usaha tak terlepas dari hambatan yang dialami dalam mengembangkan usaha tersebut termasuk home industry kerudung. Dalam mengembangkan usahanya hambatan yang dialami oleh pemilik usaha ini adalah modal, dan pegawai, dengan adanya modal yang cukup besar dapat menyediakan fasilitas dan prasarana yang memadai untuk berlangsungnya kegiatan produksi kerudung, dan jumah pegawai yang berkualitas turut berperan penting sehingga produk barang yang dihasilkan dapat berkualitas dan dapat menghindari adanya kesalahan yang terjadi. Kurangnya jumlah 
pegawai dapat menghambat kegiatan produksi sehingga pengelola akan ikut serta dalam proses produksi hal ini dilakukan agar kerudung yang dihasilkan dapat selesai tepat waktu sesuai dengan pesanan.

\section{DAFTAR PUSTAKA}

Chabib Soleh. Dialektika Pembangunan dengan Pemberdayaan, Bandung: Fokusmedia

Horton dan Hurt,(1987 : 59) lihat dalam Damsar, dan Indrayani, Pengantar Sosiologi Ekonomi (Jakarta : Kencana, 2009) hal 5

Kartasasmita, Ginanjar. 1995 Ekonomi Rakyat : Memadukan Pertumbuhan dan Pemerataan : Jakarta : CIDES, 1995

Kindervatter, S. (1979). Nonformal Education As An Empowering With Studies From

Lexy J Moleong, Metode Penelitian Kualitatif, Bandung : Remaja Rosda Karya, 2002

Milles, Mathes B dan Huberman, Michael 1992. Analisis Data Kualitatif terjemahan, Tjetjep Rohendi Rohidi. Jakarta :UI Press

Moeloeng, Lexy J 2002 Metodologi Penelitian Kualitatif Bandung : Sinar Baru Algesindo

Prof. Dr. Hamid Darmadi, M Pd. Metode Penelitian Pendidikan dan Sosial, Bandung : Alfabeta

Prof. H. D. Sudjana S. Pendidikan Nonformal ( Nonformal Education), Bandung : Falah Production 2010

Riyanto, Astim dan Arifah.(2013). Kapita Selekta Kewirausahaan. Bandung : Yapemdo

Robert Bogdan dan Steve Tylor. 1992 Pengantar Metode Penelitian Kualitatif Suatu Fenomenologis Terhadap Ilmu-ilmu Sosial terjemahan Ali Furhan. Surabaya : Usaha Nasional

Suharsimi. Arikunto, Prosedur Penelitian Suatu Pendekatan Praktek, Jakarta : Rineka Cipta, 1996

Suhendra, 2006 Peranan Birokrasi dalam Pemberdayaan Masyarakat. Bandung : Alfabeta

Tohar, M (2000), Industri Kecil. Bandung, Remaja Rosda Karya.

Yunus, M (2004). Menciptakan Dunia Tanpa Kemiskinan : Bagaimana Bisnis Sosial Mengubah Kehidupan Kita. Jakarta : Gramedia Pustaka Utama 